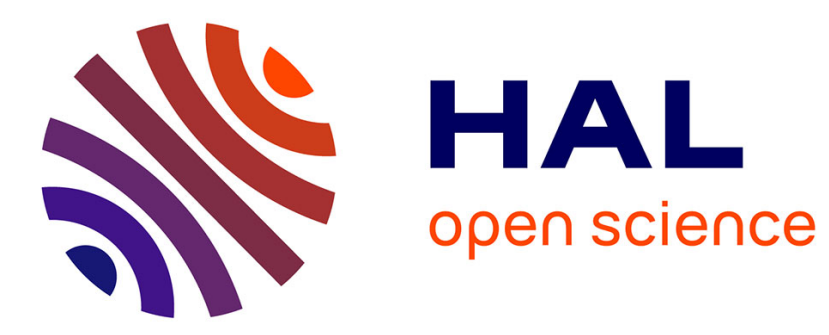

\title{
Achievements and prospects of advanced materials processed by powder technology
}

W. Kaysser

\section{To cite this version:}

W. Kaysser. Achievements and prospects of advanced materials processed by powder technology. Journal de Physique IV Proceedings, 1993, 03 (C7), pp.C7-687-C7-696. 10.1051/jp4:19937108 . jpa00251725

\section{HAL Id: jpa-00251725 https://hal.science/jpa-00251725}

Submitted on 1 Jan 1993

HAL is a multi-disciplinary open access archive for the deposit and dissemination of scientific research documents, whether they are published or not. The documents may come from teaching and research institutions in France or abroad, or from public or private research centers.
L'archive ouverte pluridisciplinaire HAL, est destinée au dépôt et à la diffusion de documents scientifiques de niveau recherche, publiés ou non, émanant des établissements d'enseignement et de recherche français ou étrangers, des laboratoires publics ou privés. 


\title{
Achievements and prospects of advanced materials processed by powder technology
}

\author{
W.A. KAYSSER \\ DLR, German Aerospace Research Establishment, Institute of Materials Research, Linder Höhe, \\ 51147 Köln, Germany
}

\begin{abstract}
In this paper examples from intermetallics, composites with ductile and high strength reinforcements, nanocrystalline and superplastic materials are used to illustrate generic and special achievements and prospects of advanced materials processed by powder technology. Processing technologies include reactive powder metallurgy, nanocrystalline processing, rapid solidification and mechanical alloying.
\end{abstract}

\section{Introduction}

The extension of initial powder metallurgy processing technologies, as solid and liquid phase sintering, to pressure assisted consolidation methods, as hot isostatic pressing (HIP), powder extrusion and powder forging, resulted in a considerable increase in the number of advanced materials processed by powder technology (PT).

PT processing of advanced materials is typically beneficial if fine grain sizes, reduced grain boundary and/or interdendritic segregation are required, as in the case of intermetallics or prematerials for superplastic forming. Rapid solidification, which is inherent to most powder metallurgical processes, results in microstructural refinement that is likely to improve ductility. Besides rapid solidification, PT processing of nanocrystalline powders obtained by chemical, physical or mechanical treatments, as mechanical alloying, can result in extremely fine microstructures. Pressure assisted consolidation methods have opened a wide field of powder-born materials which can be fully densified at temperatures where microstructural coarsening is slow and reactions between non-compatible phases (as in most composites) are negligible.

Drawbacks of the PT techniques can be the relatively high cost of the powder production and of the further processing steps, which require an integral view on available processing facilities, consumer acceptance and long term benefits for each particular application. High cost for an advanced material may well be justified by special benefits, e.g. in aircraft turbine engines where every eliminated pound of engine weight yields annother five pounds of airframe weigth to be saved. Other drawbacks of PT materials, as higher impurity levels than in cast materials or unfavourable microstructural developments (pores or precipitations at prior particle boundaries) can be limited or avoided by strict quality control of each processing step. 


\section{Titanium Aluminides}

Alloys based on $\mathrm{Ti}_{3} \mathrm{Al}\left(a_{2}\right)$ and $\mathrm{TiAl}(\gamma)$ are of particular interest for applications in turbine engines and airframe structures in advanced aircrafts. Fig. 1 shows a complex centrifugal engine rotor produced from $a_{2}$ alloy powder (Ti-24Al-11 Nb; in at. \%) by Crucible Materials [1]. Other emerging applications are sheet materials for next century hypersonic air carriers and light-weight valves for car engines [2].

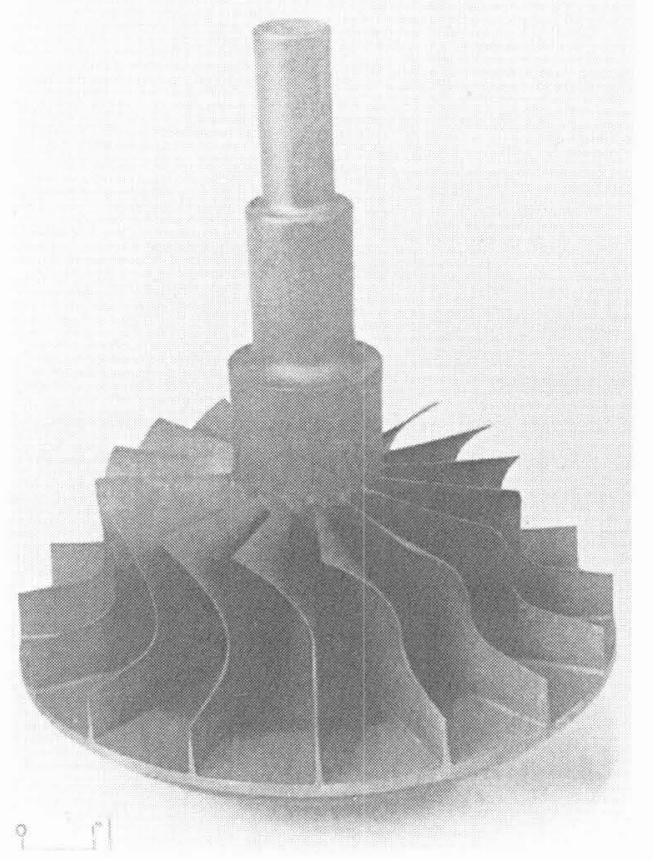

Fig.1: Centrifugal engine rotor from $\alpha_{2}$ Ti alloy powder [1].

The primary advantages of titanium aluminides are low density, high strength-to-weight ratio at elevated temperatures, good elevated temperature creep-rupture strength, a higher modulus than conventional titanium alloys, and good oxidation resistance. Design studies projected considerable weight savings for replacements of superalloys with Ti3Al base intermetallics, e.g. $43 \%$ in a turbine engine stator support ring [3].

PT offers potential for reducing some processing problems and costs inherent to the Tibase intermetallics. Powder manufacturing methods include rotating disc atomization, plasma rotating electrode process and gas atomization [1,4]. Gas atomization has only recently been developed for use with titanium based alloys due to the difficulties associated with the interaction of crucible walls with molten titanium alloys. Contamination can be minimized when the molten metal is produced by either consumable or nonconsumable arc melting [5]. Subsequent atomization through an annular gas flow nozzle yielded comparatively coarse (average $200 \mu \mathrm{m}$ ) but clean powders [3]. Other methods include skull melting or advanced contact-free melting and guidance through the nozzle region [6] which allows safe homogenization for complex titanium alloys containing elements of widely different melting points [1]. 
Consolidation is achieved either by extrusion, HIP or superplastic forging. The titanium aluminide alloys usually require temperatures in excess of $980^{\circ} \mathrm{C}$ and extrusion ratios greater than 5:1 to attain full density. Following extrusion, the materials are fabricated to final shapes using hot working techniques (e.g. isothermal forging) and/or machining. After extrusion in the $\left(a_{2}+\beta\right)$ phase field the $a_{2}$ alloy microstructures are nearly equiaxed $a_{2}$ grains separated by a worked Widmannstätten structure. As-extruded $\gamma$ alloys can be extremely fine grained. For HIP or HIP-related processes similar temperatures and pressures in excess of $100 \mathrm{MPa}$ are required to produce near-net shapes from prealloyed powder. The $a_{2}$ microstructure of HIPed material consists of primary $a_{2}$ grains in a transformed $B$ matrix. The $B$ matrix transforms to a fine scale Widmannstätten structure during cooling from HIP temperature. The microstructure of as HIPed $\boldsymbol{r}$-TiAl consists of a bimodal distribution of nearly equiaxed grains containing a fine lamellar $\left(a_{2}+v\right)$ structure.

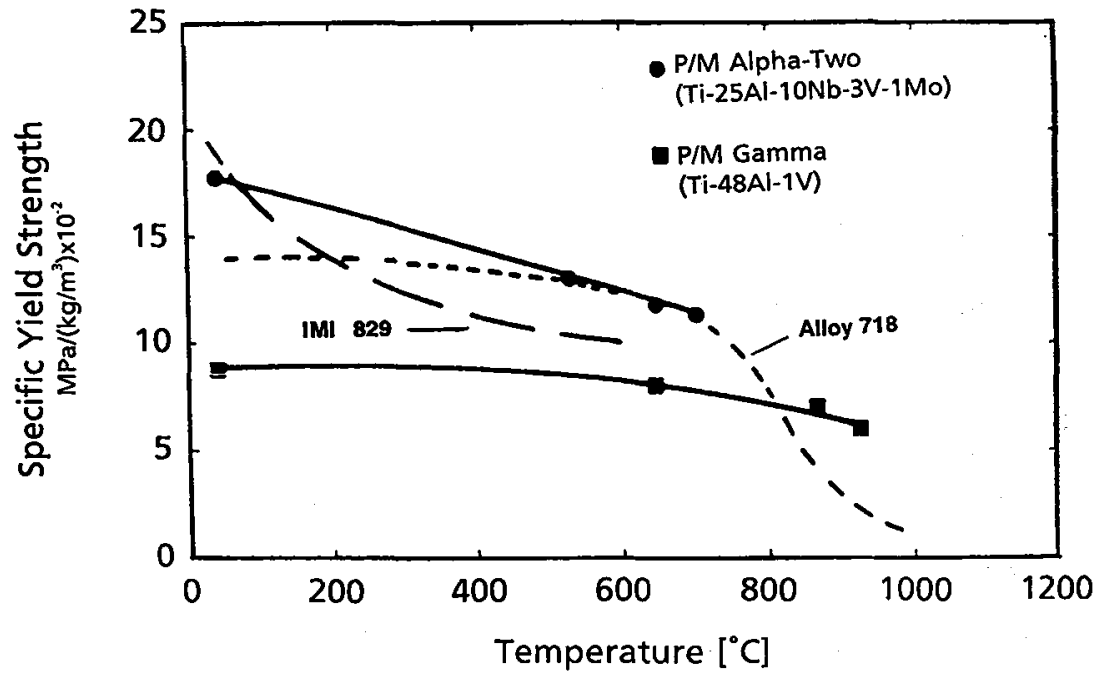

Fig.2: Comparison of specific yield strengths of titanium aluminides, titanium and nickel based alloys as a function of temperature (1).

Titanium aluminide alloys produced from powder mostly have properties equivalent to those of cast and wrought products [1]. The yield strength of two titanium aluminde alloys produced by PT are compared with other titanium and nickel based alloys on a densitycorrected basis in Fig.2. The $a_{2}$ alloy (Ti-25Al-10Nb-3V-1Mo; in at.\%) was HIPed at $1038^{\circ} \mathrm{C}$, solution treated and aged. At temperatures up to $700^{\circ} \mathrm{C}$ the specific yield strength of this alloy is superior to both, the IMI 829 (Ti-5.5Al-3.5Sn-3Zr-0.3Mo-1 Nb$0.3 \mathrm{Si}$, in $\mathrm{wt} . \%$ ) and the alloy 718 (Ni-19Cr-3Mo-5.1 Nb-0.5Al-0.9Ti-18.5Fe-0.04C; in wt. \%). IMI 829 is a creep resistant conventional titanium alloy and the Inconel alloy 718 is a widely used Ni-based superalloy. The gamma alloy (Ti-48Al-1V; in at.\%), shown in Fig.2, was HIPed at $1149^{\circ} \mathrm{C}$ and cooled without further heat treatment before measuring the mechanical properties.

\section{Nickel Aluminides}

As future bullk material the ordered $\mathrm{B} 2$ ( $\mathrm{CsCl}$ ) phase NiAl has a higher potential to be processed by $\mathrm{PT}$ methods than $\mathrm{Ni}_{3} \mathrm{Al}$, due the extremely limited formability of $\mathrm{NiAl}$ at temperatures $<600^{\circ} \mathrm{C}$. Particular remedies of improving ambient temperature strength and 
toughness are macroalloying [7], microalloying, grain refinement [8], and utilization of fibrous second phases or particles for reinforcement [9]. A recent review article by Stoloff and Alman [10] describes PT and other innovative processing techniques for the fabrication of intermetallic matrix composites in detail.

A recent study (7) revealed the beneficial effect of ternary alloying with 5 at. \%Nb or 5 at. \% Ti on the mechanical properties of stoichiometric NiAl at room temperature and on the creep properties at elevated temperatures. Attritor milling of the Ar-atomized powders for $20 \mathrm{~h}$ under flowing Ar was followed by sintering of ClPed compacts for $2 \mathrm{~h}$ under hydrogen and subsequent HIPing to complete density without encapsulation. The approximately 4-fold increase in fracture toughness of the ternary alloys over the binary $\mathrm{NiAl}$ is as significant, as is the change in fracture path from intergranular to transgranular upon alloying with $\mathrm{Ti}$ or $\mathrm{Nb}$.

\section{Reactive Powder Technology}

Also self sustaining combustion synthesis (SHS) of powders is a commercially used processing method, reactive sintering of preforms on the basis of SHS is in its infancy. Sintering of preforms from compacted elemental powder mixtures would an economically most attractive method to obtain parts, e.g. from $y$-TiAl. Elemental $\mathrm{Ti}$ and Al powders with or without additives lother elements as e.g. $\mathrm{Cr}, \mathrm{Mn}, \mathrm{Nb}$ or short fibres or particles such as $\mathrm{Al}_{2} \mathrm{O}_{3}$ and $\mathrm{TiB}_{2}$ ) are randomly mixed in the desired ratio and precompacted in air or protective gas, to reduce the enclosed oxygen content [11]. The addition of extra elements can be achieved by the use of prealloyed powders [12]. Precompaction is essential for the elemental powder metallurgy (EPM) of titanium aluminides and may be conducted by uniaxial or isostatic pressing and subsequent extrusion, drawing, rolling, forging or swaging [12] to destroy the oxide layers at the powder surfaces and to allow for metallic bonding between the initial particles.

The deformed preforms can be machined to components with complex shapes. No intermetallic phases are intended to form before machining. The formation of the titanium aluminides is realized by reactive annealing (there will be no sintering in its strict meaning, due to the absence of pores). The reaction of elemental $\mathrm{Ti}$ and $\mathrm{Al}$ powders to the intermetallic phase TiAl proceeds through an intermediate step in which the intermetallic phases $\mathrm{Al}_{3} \mathrm{Ti}$ and $\mathrm{Al}_{2} \mathrm{Ti}$ exist. Unfortunately, Kirkendall pores forming during solid state interdiffusion, macro pores forming during flow and subsequent reaction of liquid $\mathrm{Al}$ and solid $\mathrm{Ti}$ as well as the interdiffusion of $\mathrm{Al}_{3} \mathrm{Ti}$ and unreacted $\mathrm{Ti}$ forming intermetallic phases of higher density (TiAl and $\mathrm{Ti}_{3} \mathrm{Al}$ ) cause considerable swelling and residual porosity during sintering, i.e. pressure assisted consolidation methods are required to manufacture dense products by reaction synthesis. Up to now, the mechanical properties of $\mathrm{TiAl}(\mathrm{X})$ materials obtained by elemental powder metallurgy are limited by high oxygen contents and processing flaws [12].

Elemental powder processing or reactive sintering of $\mathrm{Ni}$ aluminides has been reported in detail by $(13,14)$. To date, $\mathrm{Ni}_{3} \mathrm{Al}$ with a relative density of up to $97 \%$ has been achieved by optimizing reaction sintering parameters, including particle size, heating rate and atmosphere. Parts with high density $(99.3 \%)$ can be obtained by applying a low compressive stress (50 $\mathrm{MPa}$ ) during reactive consolidation and subsequent vacuum annealing to complete the reaction. Monlithic NiAl and NiAl matrix composites can be fabricated from reactive synthesis approach as long as prealloyed NiAl (10 to $25 \mathrm{wt}$ \%) is present to dilute the exothermic reaction between $\mathrm{Ni}$ and $\mathrm{Al}$. The optimal fabrication route proposed for $\mathrm{NiAl}$ is reaction sintering followed by HIP [9]. 


\section{Composites}

\subsection{Particulate Reinforced Materials}

The main candidates for the substitution of already existing materials by particle reinforced materials are light alloys where the reinforcement additions enhance specific stiffness and perhaps also yield some improvement in strength at elevated temperatures. The relative benefits of the conventional powder metallurgy route in terms of microstructural versatility are set against the relatively high intrinsic costs that arise from a multiplicity of batch processing steps. Co-spray deposition as one of the more mature alternative powderrelated processing options, trades some microstructural versatility for potential cost saving. Proposed MMC applications have succeeded to the point of small production run orders, but aerospace industry seems not yet convinced that MMC can substitute for major established materials. Al matrix composites like co-sprayed $2014 / \mathrm{SiC}_{\mathrm{p}}-\mathrm{T} 6$ or $6061 / \mathrm{SiC}_{\mathrm{p}}$-T6 have achieved remarkable mechanical properties as $\mathrm{YS}=466 \mathrm{MPa}, \mathrm{E}=$ $100.4 \mathrm{MPa}, \epsilon=2.0 \%$ and $\mathrm{YS}=342 \mathrm{MPa}, E=91.5 \mathrm{MPa}, \epsilon=3.2 \%$ ( $\mathrm{YS}=$ yield strength, $E=$ Youngs modulus, $\epsilon=$ elongation to fracture) [15].

A second category of MMCs holds the key to successful systems development. For example a combination of specific strength or stiffness at elevated temperature, not obtainable with presently developed materials may be the essential requirement of a viable hypersonic transport vehicle. Powder technology relies in this case on its technological absolute merit compared to other technologies as demonstrated in $\mathrm{Ti}_{3} \mathrm{Al} / \mathrm{SiC}$ and $\mathrm{Al}_{3} \mathrm{Ta} /-$ $\mathrm{Al}_{2} \mathrm{O}_{3}$ systems. Seybolt [16] mechanically alloyed $\mathrm{NiAl}$ with $\mathrm{Al}_{2} \mathrm{O}_{3}, \mathrm{Y}_{2} \mathrm{O}_{3}$ and $\mathrm{ThO}_{2}$ particles. The particles improved the high temperature tensile properties of NiAl. The effect of fine $\mathrm{TiB}_{2}(1$ to $3 \mu \mathrm{m})$ has been studied [17] and Martin Marietta "s proprietary XD process has been employed to fabricate NiAl dispersed with 2.7 to $30 \mathrm{vol}$. $\% \mathrm{TiB}_{2}$ particles. These particles significantly improved the compressive strength of stoichiometric NiAl; the addition of $30 \mathrm{vol} . \% \mathrm{TiB}_{2}$ improved the compressive flow stress of $\mathrm{NiAl}$ at $1027^{\circ} \mathrm{C}$ from 25 to $95 \mathrm{MPa}$ at a strain rate of $2 \times 10^{-6} \mathrm{~s}^{-1}(18)$. The same process was used to disperse fine $\mathrm{TiB}_{2}$ particles in $\mathrm{NiAl} / \mathrm{Ni}_{2} \mathrm{AlTi}$ [19] alloys, CoAl and Ti-45at.\%Al. Kumar improved the fracture toughness of $\mathrm{NiAl}$ and $\mathrm{NiAl} / \mathrm{TiB}_{2}$ alloys by reinforcement with $15 \mathrm{vol} . \% \mathrm{Al}_{2} \mathrm{O}_{3}$ whiskers from 6 to $9 \mathrm{MPa} / \mathrm{m}$. Fabrication of NiAl composites with either chopped fibrous $\mathrm{Al}_{2} \mathrm{O}_{3}$ (Dupont-FP, $20 \mu \mathrm{m}$ in diameter, $5-30 \mathrm{~mm}$ in length) or with particulate $\mathrm{TiB}_{2}(3 \mu \mathrm{m})$ provided composites with high compressive strength at room temperature which increased from 1000 to $1915 \mathrm{MPa}$ by addition of up to $40 \mathrm{vol} . \% \mathrm{TiB}_{2}$.

\subsection{Long Fiber Reinforced Material}

Long fiber reinforced metal matrix composites (MMC) are essentially survivor materials which may hold the key to some successful systems developments. At present, costs of these materials are astronomically high due to the prizes for long fibers and manual composite processing. Nevertheless, these MMCs show specific properties not achieved by any other type of material. SiC long fiber reinforced titanium alloys are presently mainly processed by hot pressing of alternating layers of titanium alloy (foils or plasma sprayed) and fibers.

A suitable PT method is based on coating of fibers with the Ti alloy matrix and subsequent HIP of fiber bundles. Fig. 3 shows a SiC fiber (SCS-6, Textron Speciality Materials, Lowell, MA) coated with Ti6Al4V by magnetron sputtering. Under optimized consolidation conditions HIP of the wound fiber bundles yields pore free material by superplastic deformation of the fine grained $\mathrm{Ti}$ alloy matrix (Fig.4) [22]. The fiber coating and HIP method yields SiC reinforced Ti alloys with properties shown in Fig. 5 for the matrices Ti6Al4V and IMI 834. 
Parts and materials on the basis of long SiC fiber fabrics woven with Mo wires and metallized by plasma spraying with $\mathrm{Ti}, \mathrm{Al}$ or $\mathrm{Cu}$ alloys are under development.

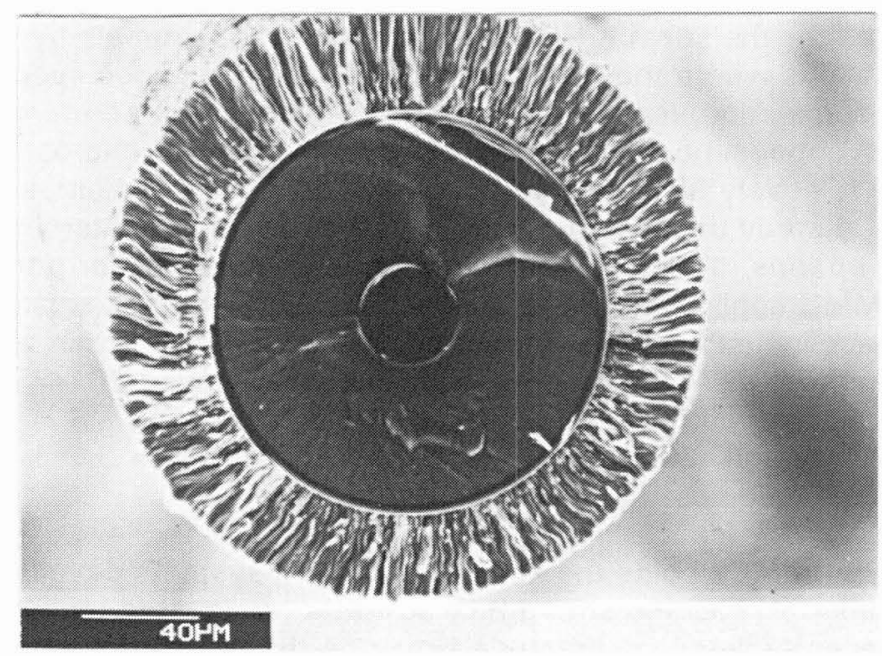

Fig.3: SiC-fiber coated with Ti6Al4V by magnetron sputtering.

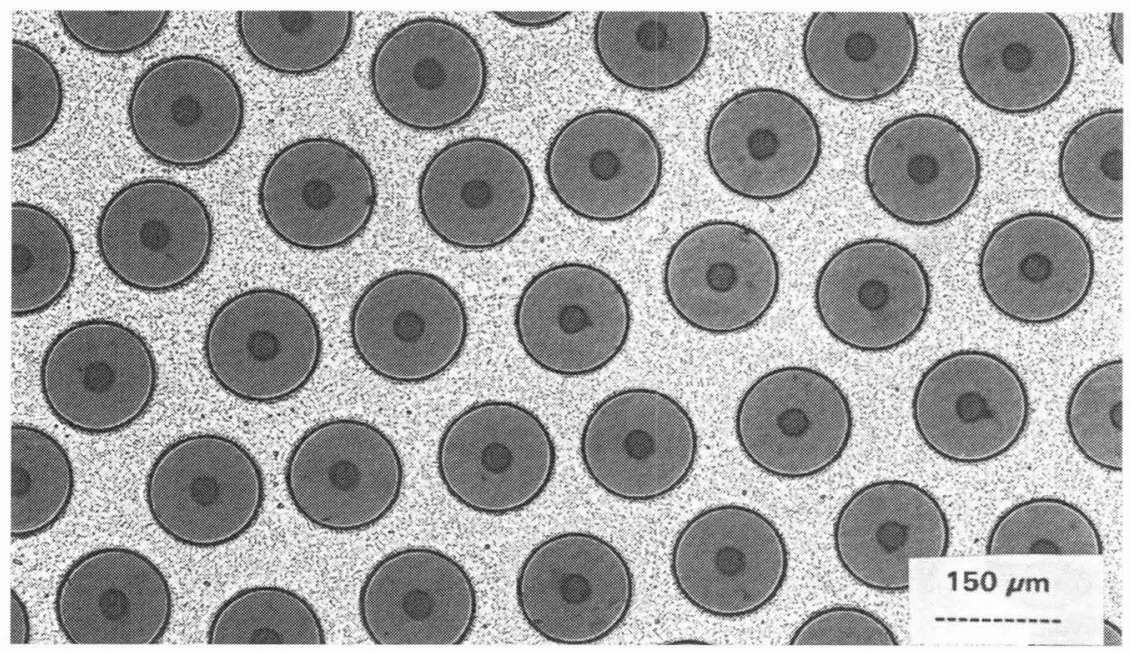

Fig.4: $\mathrm{SiC} / \mathrm{Ti} 6 \mathrm{Al} 4 \mathrm{~V}$ composite from wound and HIPed fibers.

As mentioned above, the fabrication of NiAl composites with 40 vol. \% of chopped fibrous $\mathrm{Al}_{2} \mathrm{O}_{3}$ (Dupont-FP, $20 \mu \mathrm{m}$ in diameter, $5-30 \mathrm{~mm}$ in length) also provided an outstanding increase of the compressive strength at room temperature. Brindley [20] prepared $\mathrm{Ti}_{3} \mathrm{Al}$ powder cloths from prealloyed powders; these cloths were interspersed with layers of continuous $\mathrm{SiC}$ fibres and consolidated by hot pressing. Anton [21] infiltrated an $\mathrm{Al}_{2} \mathrm{O}_{3} \mathrm{fi}-$ brous preform with elemental $\mathrm{Al}$ and Ta powders. Consolidation of the composites or of the $\mathrm{Al}_{3} \mathrm{Ta}$ matrix was performed by reactive hot pressing. 


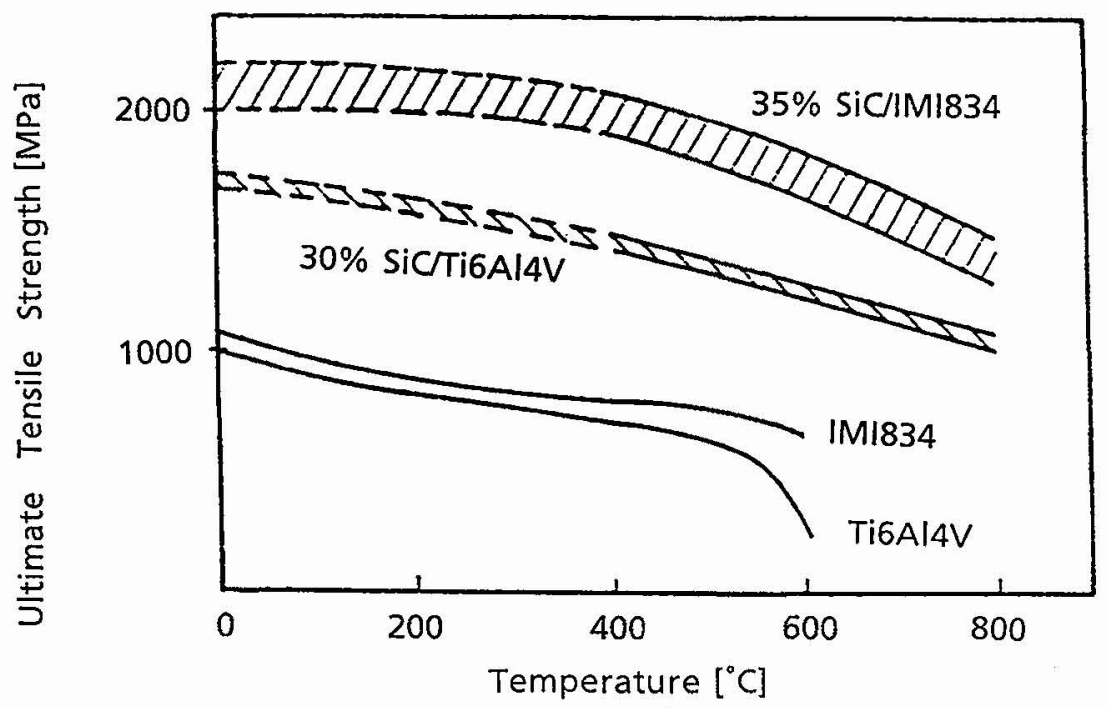

Fig.5: Improved ultimate tensile strength of SiC long fibre reinforced $\mathrm{Ti}$ alloys.

\section{Nanocrystalline Materials}

Nanocrystalline materials are characterized by an extremely large number of internal interfaces that may promote dynamic processes needed for superplastic forming or low temperature sintering (Fig.6). Applications are seen for the sensor technology and other applications, i.e. for damping devices [23]. The dominant mechanical property change resulting from reducing the grain size of nanocrystalline metals is the significant increase in their strength. In the as-consolidated state nanocrystalline Pd samples with $5-10 \mathrm{~nm}$ grain sizes exhibit up to $500 \%$ increase in hardness over coarser grained $(100 \mu \mathrm{m})$ samples [24]. Similar results have been observed in nanocrystalline copper as well. The increased strength of nanocrystalline metals and the increased ductiliy of nanophase ceramics indicate a convergence of the mechanical response of these two classes of materials as grain sizes enter the nanometer range.

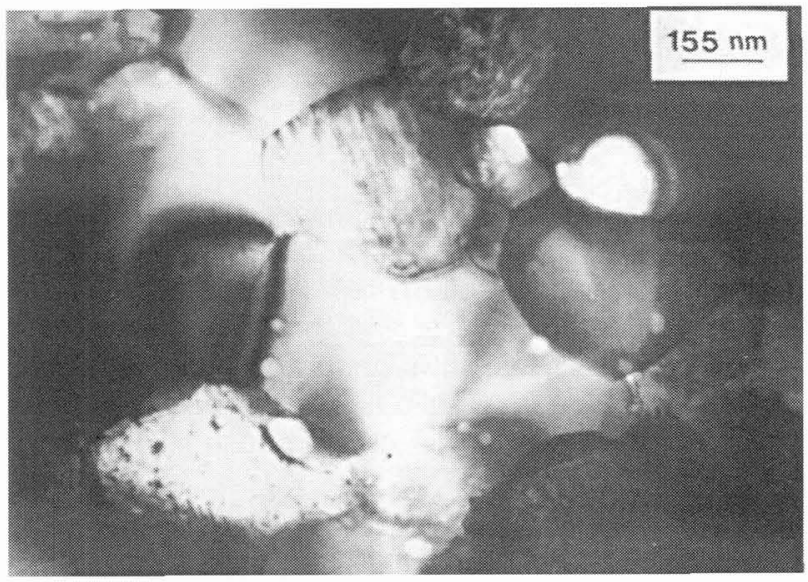

Fig.6: Plasma activated sintered Nb - 15at.\%Al from mechanically alloyed composite powder (TEM) [27]. 
Up to now measurements of sintering charcteristics of most nanocrystalline metal alloy powders have been hampered by the formation of oxides at the reduced sintering temperatures [25]. The often quite rigid necklace-type structures formed by the nanocrystalline grains yield larger porous defects after cold compaction which are hardly removed during sintering, even if additional external pressure is applied. Fig. 9 [26].

\section{PT Materials for Superplastic Forming}

For a beneficial application of superplastic forming in production considerably shortened forming times of less than one minute and equivalently high forming and strain rates in excess of $0.1 \mathrm{~s}^{-1}$ are essential. Recently, a number of PT composites have shown isothermal superplasticity during deformation in this range of strain rates (HSRS) [27].

Fig. 7 shows the elongation-to-failure as a function of strain rate for various $\mathrm{Al}$ alloys. These include $7475 \mathrm{Al}, 2090 \mathrm{Al}-\mathrm{Li}$ alloy, the commercial Supral alloys, $\mathrm{Al} / \mathrm{SiC}_{\mathrm{w}}$ ( $\mathrm{w}$ and $\mathrm{p}$ indicate whiskers or particles, respectively), and $\mathrm{Al} / \mathrm{Si}_{3} \mathrm{~N}_{4}$ composites, a $\mathrm{Zr}$-modified 2124 $\mathrm{Al}$ and mechanically alloyed 9021 . It is evident that there is an increased strain rate for optimal superplastic flow with a decrease in grain size [28].

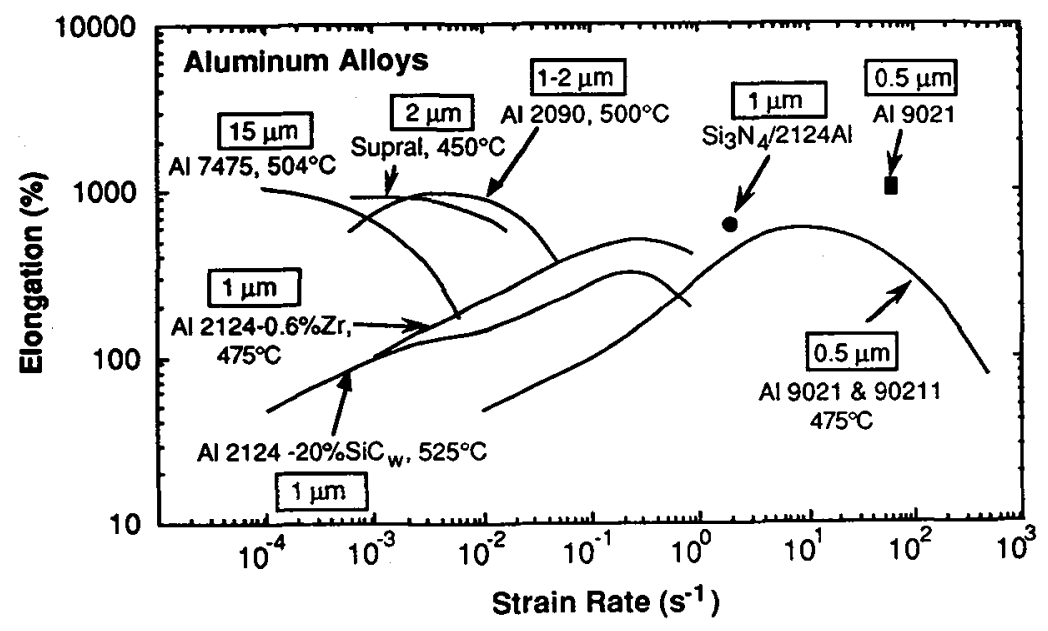

Fig. 7: The elongation-to-failure as a function of strain rate for various Al alloys [28].

The origin of high-strain-rate-superplasticity (HSRS) of the particulate reinforced PT materials is connected to their reduced grain size and the large number of metal/ceramic interfaces. Besides grain boundary sliding, which is generally believed to be the dominant deformation mode in fine-grained, superplastic alloys, the formation of minor amounts of liquid phase at the metal/ceramic interfaces is thought to cause HSRS [28].

The PT process yields prematerials with a very fine, equiaxed, homogeneous grain structure which is an essential condition for optimized superplastic forming. An example of PT processed prematerials are ultrahigh carbon steels (UHC-steel) which are superplastically formed by isothermal forging [29]. They contain 2.5 wt. \% C, 5.3 wt. \% Cr, 9.8 wt. \% V, 
small amounts of Mo and Mn and the balance Fe. They are designed for cold working applications such as extruder scews for paper recycling machines. Inert gas atomized powders (av. particle diameter $<45 \mu \mathrm{m}$, inner grain size $<2 \mu \mathrm{m}$ ) are consolidated by HIP at $100 \mathrm{MPa}, 1180^{\circ} \mathrm{C}$ for $4 \mathrm{~h}$. Under these conditions only minor microstructural coarsening occur. The HIPed material is superplastically forged at temperatures slightly above $1000^{\circ} \mathrm{C}$ and strain rates between $10^{-3}$ and $10^{-2} \mathrm{~s}^{-1}$.

The cost saving potential of superplastic forming is well established for $(\alpha+\beta) \mathrm{Ti}$ alloys. This is documented by a variety of areospace parts which have been produced through this technique, often in combination with diffusion bonding [30]. A typical example of superplastic forging of Ti alloys is Protasul 100, an $\alpha+\beta$ alloy with $6 \mathrm{wt} \% \mathrm{Al}$ and 7 $\mathrm{wt.} \% \mathrm{Nb}$. The biocompatible alloy requires no particular thermal treatment to achieve superplasticity at temperatures between 900 and $930^{\circ} \mathrm{C}$. Wing parts of a N707 Al1 $1 \mathrm{Zn} 2.4 \mathrm{Mg} 1.1 \mathrm{Cu}$ alloy have been produced by superplastic forging of spray deposited (Alusuisse Lonza) blanks [29]. The fine grained material (5-9 $\mu \mathrm{m}$ ) showed superplastic behaviour at 400 to $450^{\circ} \mathrm{C}$ with a strain rate sensitivity between 0.31 and 0.44 .

\section{Mechanical Alloying}

During intensive milling of powder blends continuous fracture, microforging and solid state diffusion events can provide alloying on an atomic scale (mechanical alloying). Since the early 70 s a variety of materials including immiscible systems, metal ceramic composites, intermetallic and ceramic compounds have been synthesized by this method. The favourable properties of these materials result mainly from their overall chemical and microstructural homogeneity which, in general, cannot be achieved by conventional techniques [31].

The unique possibility to achieve a homogeneus distribution of nanometer-sized oxide particles in a metallic matrix enables the preparation of $\mathrm{Ni}$-, $\mathrm{Fe}$ - and $\mathrm{Al}$-based ODS alloys for structural applications at temperatures close to their melting point. At present, this represents still the major technical field of the mechanical alloying process and will be described here for a Ni-base ODS alloy in more detail.

Conventional $\mathrm{Ni}$-base superalloys for turbine blades rely for much of their strength on the precipitated $y^{\circ}$ phase. This phase may start to coarsen at temperatures $>850^{\circ} \mathrm{C}$ and shows partly or complete dissolution above $1000^{\circ} \mathrm{C}$. ODS alloys as MA6000 (Inco Alloys) contain fine oxide dispersoids. Their presence allows higher $\mathrm{Cr}$ and lower refractory metal $(\mathrm{W}, \mathrm{Mo})$ contents than in conventional alloys for the sake of better oxidation resistance and lower density without sacrifice in creep strength. MA6000 contains 2.5 vol. \% of $\mathrm{Y}_{2} \mathrm{O}_{3}$ particles in the nanometer size range, appr. $50 \%$ by volume of $\gamma^{\prime}$ phase comprising $\mathrm{Ni}, \mathrm{Al}$, $\mathrm{Ti}$ and $\mathrm{Ta}$. Solid solution strengthening comes from moderate additions of the refractory elements $\mathrm{Mo}$ and $\mathrm{W}$. Oxidation resistance is provided by $15 \mathrm{wt} \% \mathrm{Cr}$ and $4.5 \mathrm{wt}$. \% Al. A balanced combination of $\mathrm{Ti}, \mathrm{Ta}$ and $\mathrm{Cr}$ ensures protection against sulphidation [32]. At lower temperatures, however, the strength of MA6000 is inferior to the strength of conventionally cast single crystal superalloys. The potential of MA6000 is thus best used in small size turbine engines running at high temperatures. Moderate tensile stresses are becoming operative at the root of the short and light weight blades at a position which runs at less than $700^{\circ} \mathrm{C}$. A recent commercial application as solid first stage blades for a newly designed land based gas turbine (1.6 MW, EGT hurricane engine) yields electricity generation at high efficiency due to a gas inlet temperature of $1134^{\circ} \mathrm{C}$ [32]. 


\section{References}

[1] MOLL J.H., C.F.Yolton, B.J.McTiernan, J.Powder Metallurgy, 26(1990)149).

[2] Programm Materialforschung des BMFT, Jahresbericht 1991, ISSN 0724-1711.

[3] HOLOWACH J., T.K.Redden, Oct. 1978, AFAPL-TR-78-74, General Electric Co. Cincinnati, $\mathrm{OH}$.

[4] ADAMS M.L., S.L.Kampe, L.Christodoulou, J. Powder Metallurgy, 26(1990)105.

[5] ANDERSON R.E. Jr., Defense Technologies Conference, Seattle, WA, Nov. 2-3, 1989, MPIF, Princeton, NJ.

[6] WAGNER R. in (2), (1991)483.

[7] KAYSSER W.A., R.Laag, J.C.Murray, G.Petzow, Int. J. Powder Metallurgy, 27(1) (1991)43.

[8] SCHULSON E.M., D.M.Barker, Scripta Met. 17(1983)519.

[9] ALMAN D.E., N.S.Stoloff, 27(1991)29.

[10] STOLOFF N.S., D.E.Alman, (eds.) D.L.Anton, R.McMeeking, D.Miracle, P.Martin, MRS, Symposia Proc., MRS Pittsburgh, PA, 1993, in print.

[11] DAHMS M., F.Schmelzer, G.Leitner, W.Pößnecker, S.Schultrich, Z. Metkde., 84 (1993) 351.

[12] WANG G.-X., M.Dahms, Powder Metallurgy International, 24(1992)219.

[13] BOSE A., B.H.Rabin, R.M.German, Powder Met. Int., 20(1988) 25.

[14] NISHIMURA C., C.T.Liu, Acta Met.et Mater. 41(1993)113.

[15] FEST A., Metal Powder Report, Oct.(1992)40.

[16] SEYBOLT A.U., Trans. ASM, 59(1966)860.

[17] WHITTENBERGER J.D.Whittenberger, S.Kumar, K.S.Mannan, R.K.Viswanadam, Mat.Sc.Lett., 9(1990)326.

[18] WHITTENBERGER J.D., R.K.Viswanadham, S.K.Mannan, B.Sprissler, Mat.Sc. $25(1990) 35$.

[19] KUMAR K.S., S.K.Mannan, J.D.Whittenberger, R.K.Viswanadham, L.Christodoulou, 1989, MML-TR-89-102(C).

[20] BRINDLEY P.K, in "High Temperature Ordered Intermetallic Alloys II, 1987", (eds.) N.S.Stoloff, C.C.Koch, C.T.Liu, O.lzumi, MRS, Pittsburgh, PA, 81(1987)419.

[21] ANTON D.L, in "High Temperatures/High Performance Composites", (eds.) F.P.Lemkey, S.G.Fishman, A.G.Evans, J.R.Strife, MRS, 120(1988)57.

[22] LEUCHT R., H.J.Dudek, submitted to Mat.Sci. Eng.

[23] GÜNTHER B., A.Kumpmann, H.-D.Kunze, , Scripta met.et mat., 27(1992)83.

[24] NIEMANN G., W.Weertman and R.W.Siegel, Scripta Met. 23(1989)2013.

[25] SAKKA Y., T.Uchikoshi, E.Ozawa, J. Mat. Science, 28(1993) 203.

[26] BOURELL D.L., P. Parimal, W.A.Kaysser, J.Am.Cer.Soc., 76/3(1993)705.

[27] TRACY, M.J., J.R.Groza, J.Mat.Science, 28(1993)203.

[28] NIEH T.G., J.Wadsworth, JOM, Nov. (1992)46.

[29] LAAG R., K.Peichl, E.Heisig, E.Brühlmann, U.Giegel, in Advances in Powder Metallurgy and Particulate Materials - 1992", vol 7, Novel Powder Processing, compiled by J.M.Capus and R.M.German, MPIF, Princeton, NJ, (1992) 245.

[30] WINKLER P.-J., Aluminium 60(1984)261.

[31] BORMAN R., in "Materials by Powder Technology - PTM'93, (ed.) F.Aldinger, DGMInformationsgesellschaft - Verlag, Oberursel, (1993)247.

[32] HACK G., Metal Powder Report, Oct.(1992) 24. 